\title{
The Role of Humic Acid and Proline on Growth, Chemical Constituents and Yield Quantity and Quality of Three Flax Cultivars Grown under Saline Soil Conditions
}

\author{
Bakry Ahmed Bakry ${ }^{*}$, Moamen Hamed Taha², Zainab Ahmed Abdelgawad ${ }^{3}$, \\ Maha Mohamed Shater Abdallah4 \\ ${ }^{1}$ Field Crops Department, National Research Centre, Dokki, Egypt \\ ${ }^{2}$ Agronomy Department, Faculty of Agriculture, Cairo University, Giza, Egypt \\ ${ }^{3}$ Botany Departments, Women's College, Ain Shams University, Cairo, Egypt \\ ${ }^{4}$ Botany Departments, National Research Centre, Dokki, Egypt \\ Email: Bakry_ahmed2004@yahoo.com
}

Received 19 October 2014; revised 16 November 2014; accepted 3 December 2014

Copyright (C) 2014 by authors and Scientific Research Publishing Inc.

This work is licensed under the Creative Commons Attribution International License (CC BY). http://creativecommons.org/licenses/by/4.0/

(c) (i) Open Access

\section{Abstract}

In order to mitigate the salinity effects on flax grown on moderate saline sandy soil (3275 - 3430 ppm) and irrigated with moderate saline water $(2300-2460 \mathrm{ppm})$ field experiments were carried out at the experimental Station of the Faculty of Agriculture, Wadi El-Natrun district El-Behera Governorate-Egypt, during two successive winter seasons of 2012/2013 and 2013/2014. Three flax varieties (Opal, Giza-8 and Mayic) were grown and treated with some chemical additives humic acid (50 kg/fed) and/or foliar applied proline (Control, 50 and $100 \mathrm{mg} / \mathrm{L}$ ). The results showed the positive responses of Giza-8 variety to the combined application of humic acid and proline and mitigated the salinity effects of soil and irrigation water and reflected on most of the studied characters. Such results indicate the potentiality of mitigation the hazardous effect of salinity with these chemical additives. The data indicated that the highest seed yield, straw yield and oil yield were obtained at humic acid $(50 \mathrm{~kg} / \mathrm{fed})$ with foliar treatment of proline at rate of $(100$ $\mathrm{mg} / \mathrm{L})$. The interaction of proline at $(100 \mathrm{mg} / \mathrm{L})$ with humic acid at rate of $(50 \mathrm{~kg} / \mathrm{fed})$ improved plant fresh and dry weight in all flax cultivars under salinity conditions. Fresh weight increased by $66.6 \%, 48.7 \%$ and $65.5 \%$ over controls for Opal, Giza-8 and Mayic varieties, respectively. The interaction of proline at $(100 \mathrm{mg} / \mathrm{L})$ with humic acid at rate of $(50 \mathrm{~kg} / \mathrm{fed})$ with Giza-8 variety gave the highest values of seed yield, straw yield and oil yield.

${ }^{*}$ Corresponding author.

How to cite this paper: Bakry, B.A., et al. (2014) The Role of Humic Acid and Proline on Growth, Chemical Constituents and Yield Quantity and Quality of Three Flax Cultivars Grown under Saline Soil Conditions. Agricultural Sciences, 5, $1566-1575$. http://dx.doi.org/10.4236/as.2014.514168 


\section{Keywords}

\section{Flax, Humic Acid, Proline, Seed and Oil Yield}

\section{Introduction}

Flax (Linum usitatissimum L.) is an old economic crop grown as a dual purpose crop for seeds and fibers which is used for the manufacture of linen. The oil edible and also, due to its quick dyeing properly is used for the preparation of paints, varnishes, printing ink, oil cloth and soap. In Egypt, flax plays an important role in the national economy owing to export beside local industry. Increasing the production of flax could be achieved through growing high yielding genotypes and proper fertilizer application. Flax is the second fiber crop after cotton in Egypt with regard to the cultivated area and economic importance [1]. Nowadays, the benefits of flax have passed all expectations. Flax cultivars significantly differed in yield and its attributes as well as oil content [2].

Salinity is one of the major environmental factors limiting plant growth and productivity. Salinity has become more and more important to the scientific and political agenda. Over $6 \%$ of the world's total land area and $20 \%$ of irrigated land are salt-affected (FAO, 2010). Salinity problems are particularly relevant for arid and semiarid areas like Egypt. Approximately 33\% of the cultivated land and most extension agricultural land in Egypt is already salinized [3]. The reduction in yield of different crops due to salinity in most of these areas is about $60 \%$ when compared with normal soil.

Salinity can affect growth of plant in various ways. First, the presence of salt in the soil reduces the water uptake capacity of the plant, and this causes quick reduction in the growth rate. This first phase of the growth response is due to the osmotic effect of the soil solution containing salt, and produces a package of effects similar to water stress [4]. Salinity reduces stomatal conductance greatly and consequently reduces photosynthetic rate [5]. However, the inhibition of photosynthetic rate imposed by stomatal closure may promote an imbalance between photochemical activity at photo system II (PSII) and electron requirement for photosynthesis, leading to excess excitation and subsequent photo inhibitory damage of PSII reaction centers [6].

Humic acid (HA) could be used as one of the main organic fertilizers, which is an important component of humic substances. Humic acid are the most significant constituents of organic matter in both soils and municipal waste compost, and have a relevant role in the cycling of many elements in the environment and in soil ecological functions [7]. According to previous investigations, humates seem to have a particular favorable effect on the nutrient supply. Therefore, application of humates was tested as an approach to improve both the nutrient balance and plant vitality [8]. Humic substances also promote growth, and increase yield and quality in a number of plant species [9] and [10] at least partially through increasing nutrient uptake, serving as a source of mineral plant nutrients and regulator of their release [11]. Likewise, humic substances have been shown to stimulate shoot and root growth and nutrient uptake of vegetable crops [12]. Moreover, humates influence the respirationprocess, the amount of sugars, amino acids and nitrate accumulated [8].

The accumulation of osmolytes such as proline (Pro) is a well-known adaptive mechanism in plants against salt stress conditions. Number of research works has been carried out concerning the role of Pro as a compatible osmolyte and osmoprotectant and its roles in salt stress tolerance. Several studies have attributed an antioxidant feature to Pro, suggesting ROS scavenging activity and Pro acting as a quencher [13]. Proline also, induces the expression of salt-stress-responsive proteins and may improve the plant adaptation to salt-stress [14]. Proline performs these functions by protecting the photosynthetic apparatus [15], by functioning as an oxygen radical scavenger [16], and by displaying an antioxidant activity [17] and [18]. While studying with olive trees, [19] observed that Pro supplements seemed to improve salt tolerance in olive tree by modulating some ant oxidative enzyme activities, photosynthetic activity, and thus maintained better plant growth and water status. Moreover, the decrease of soluble sugar content in Pro treated-plants revealed the important osmoprotective effect played by added Pro. The Pro application mitigated the reduction of growth and photosynthetic activity under salt stress in olive trees.

This study aimed to measure the potential roles of humic acid and/or foliar applied proline on morphological, some physiological, chemical parameters, yield quantity and quality of three flax cultivars (Opal, Giza-8 and 
mayic) grown under saline soil conditions.

\section{Materials and Methods}

Field experiments were carried out in semi-arid desert soil at the experimental Station of the faculty of Agriculture, Wadi El-Natrun district El-Behera Governorate—Egypt, during two successive winter seasons of 2012/2013 and 2013/2014. The soil of both experimental sites was Newly Reclaimed moderate saline soil where mechanical and chemical analysis is reported in Table 1 and Table 2 according to [20]. The aim of this work was to investigate effect of humic acid (50 kg/fed) to the soil with three levels foliar treatment of proline (control, 50 and $100 \mathrm{mg} / \mathrm{L}$ ) on three flax (Giza-8, Opal and Mayic) varieties grown under newly reclaimed saline soil conditions.

The experimental design was split plot design with three replications, where flax seed varieties occupied the main plots and humic acid and proline treatments were allocated at random in the sub-plots. Seeds of flax cultivars were sown on the $17^{\text {th }}$ November in both season in rows 3.5 meters long, and the distance between rows was $20 \mathrm{~cm}$ apart, Plot area was $10.5 \mathrm{~m}^{2}$ (3.0 m in width and $3.5 \mathrm{~m}$ in Length). The recommended agricultural practices of growing flax seed were applied. Pre-sowing, $150 \mathrm{~kg} /$ fed. of calcium super-phosphate $\left(15.5 \% \mathrm{P}_{2} \mathrm{O}_{5}\right)$ was applied to the soil. Nitrogen was applied after emergence in the form of ammonium nitrate $33.5 \%$ at rate of $75 \mathrm{Kg} / \mathrm{fed}$. was applied at five equal doses before the $1^{\text {st }}, 2^{\text {nd }}, 3^{\text {rd }}, 4^{\text {th }}$ and $5^{\text {th }}$ irrigation. Potassium sulfate $(48.52 \%$ $\mathrm{K}_{2} \mathrm{O}$ ) was added at two equal doses of $50 \mathrm{~kg} /$ fed, before the $1^{\text {st }}$ and $3^{\text {rd }}$ irrigations. Irrigation was carried out using the new sprinkler irrigation system where water was added every 5 days. The chemical properties of irrigation water as mentioned in Table 2 . Humic acid at rate of ( $50 \mathrm{~kg} / \mathrm{fed})$ was added to the soil after sowing and flax plants were foliar sprayed with proline at the rate of $(0.0,50$ and $100 \mathrm{mg} / \mathrm{L})$. In both seasons, foliar application of proline was carried out twice; where plants were sprayed after 45 and 60 days from sowing. Plant samples were taken after 75 days from sowing for measurements growth characters, plant height $(\mathrm{cm})$, fresh and dry weight g/plant, root length $(\mathrm{cm})$, root fresh and dry weights (g). Plant samples were dried in an electric oven with drift fan at $70^{\circ} \mathrm{C}$ for $48 \mathrm{hr}$. till constant dry weight. Plant samples were taken for chemical analysis after 75 days from sowing for chemical analysis of total soluble sugars, polysaccharides, total carbohydrates, total IAA,

\section{Table 1. Soil physico-chemical characters.}

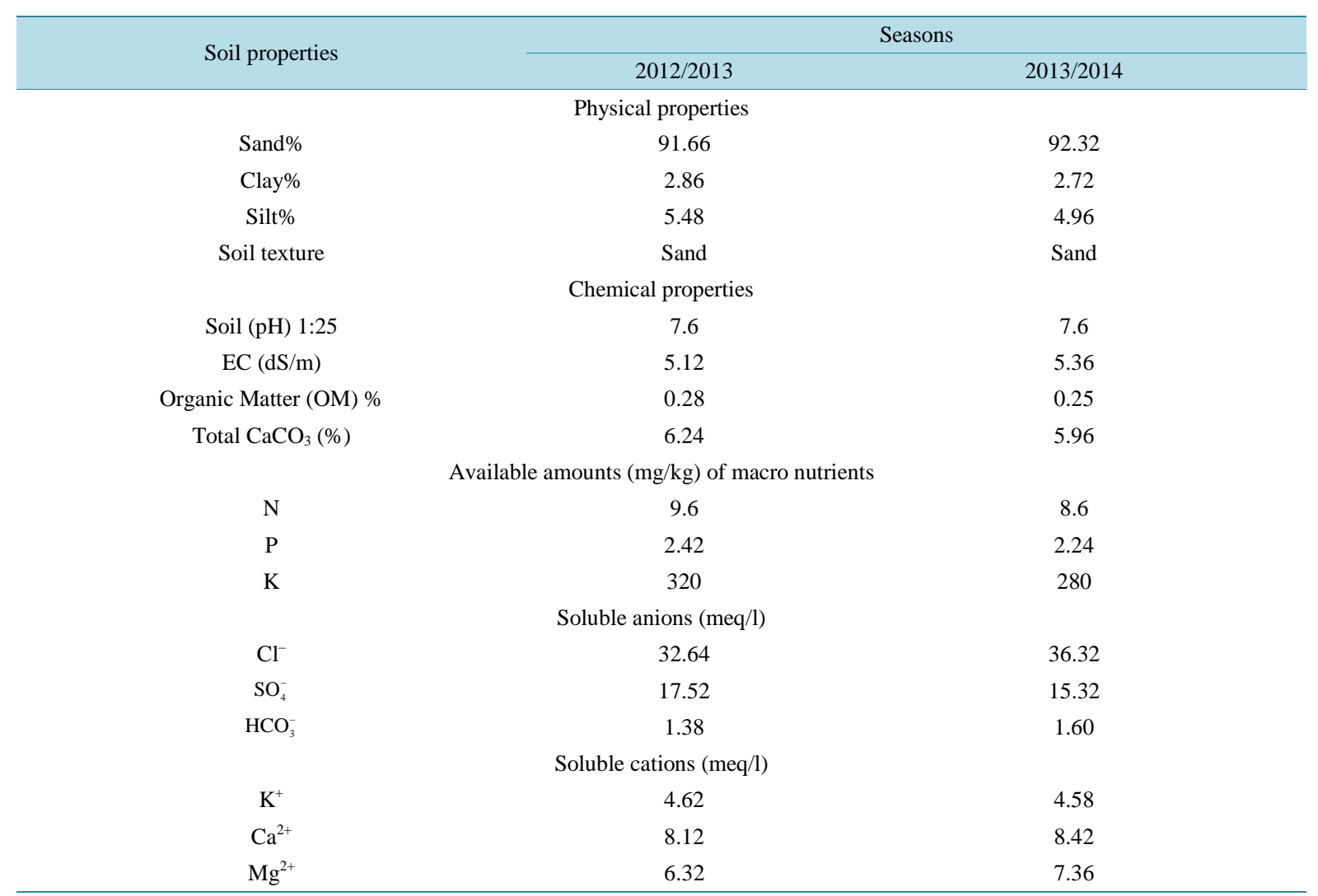


Table 2. The chemical properties of irrigation water at experimental site in 2012/2013 and 2013/2014 winter seasons.

\begin{tabular}{|c|c|c|c|c|c|c|c|c|c|c|}
\hline \multirow{2}{*}{$\mathrm{pH}$} & \multirow{2}{*}{$\begin{array}{c}\mathrm{EC} \\
\mathrm{dS} / \mathrm{m}\end{array}$} & \multirow{2}{*}{ ppm } & \multicolumn{3}{|c|}{ Soluble anions (meq/l) } & \multicolumn{4}{|c|}{ Soluble cations ( meq/l) } & \multirow{2}{*}{ SAR } \\
\hline & & & $\mathrm{HCO}_{3}^{-}$ & $\mathrm{Cl}^{-}$ & $\mathrm{SO}_{4}^{-}$ & $\mathrm{Na}^{+}$ & $\mathrm{K}^{+}$ & $\mathrm{Ca}^{2+}$ & $\mathrm{Mg}^{2+}$ & \\
\hline \multicolumn{11}{|c|}{ Season 2012/2013 } \\
\hline 7.55 & 3.84 & 2470 & 4.22 & 21.20 & 12.98 & 30.24 & 0.36 & 3.86 & 3.94 & 15.32 \\
\hline \multicolumn{11}{|c|}{ Season 2013/2014 } \\
\hline 7.50 & 3.58 & 2300 & 3.92 & 18.96 & 12.72 & 27.76 & 0.32 & 3.72 & 3.80 & 14.32 \\
\hline
\end{tabular}

total phenol content, proline, free amino acids contents and lipid peroxidation. Flax plants were pulled when signs of full maturity were appeared, then left on ground to suitable complete drying. Capsules were removed carefully. At harvest, the following characters were recorded on random samples of 10 guarded plants in each plot to estimate the following characters: Straw yield and its related characters (plant height (cm), technical stem length (cm), straw yield/plant (g), straw yield (ton/ha)). Seed yield and its related characters (number of fruiting branches/plant, number of capsules/plant, fruiting zone length, seed yield/plant (g), 1000-seed weight (g), seed yield (ton/ha), oil yield (ton/ha)) were calculated by seed yield (ton/ha) ${ }^{*}$ Seed oil percentage.

\section{Chemical Analysis}

Photosynthetic pigments: Total chlorophyll a and b, carotenoids and total pigments content in fresh plant estimated using the method of [21]. Total soluble sugars (TSS), were extracted by the method of [22]. TSS analyzed by [23]. Proline assayed according to the method described by [24]. Free amino acid content extracted according to the method described by [25]. Free amino acid was determined with the ninhydrin reagent method [26]. The oil of flax seeds extracted according to [27].

\section{Statistical Analysis}

The data statistically analyzed on complete randomized design system according to [28]. Combined analysis of the two growing seasons carried out. Means compared by using least significant difference (LSD) at $5 \%$ levels of probability.

\section{Results and Discussion}

\subsection{Effect of Flax Varieties on Growth Parameters, Chemical Constituents, Yield and Yield Components of Flax Varieties under Salinity Conditions}

The results reported in Table 3 showed that yield and yield components of flax varieties grown under saline conditions differed significantly in all characters studied. Giza-8 variety surpassed all other tested flax varieties in seed yield (1.119 ton/ha), oil yield (0.369 ton/ha) and straw yield (2.856 ton/ha). The superiority of this variety may be due to the highest values of Chlorophyll a and the Total pigment. This increase may be due to the rate of quenching of chlorophyll fluorescence, which was markedly increased in the plant leaves, and the steady state value of quenching was slightly greater than in other varieties. Moreover, the superiority of this variety may be due to the superiority in plant height, fruiting zone length, numbers of branches and capsules/plant, seed yield/plant and oil seed percentage than the other varieties. In other words, that means that Giza-8 seems to be more tolerant to salinity conditions than the other varieties. Such results are in agreement with those obtained by [29] and [30] who reported that the flax cultivars differed in seed productivity. In addition, such results indicated that the variability among tested flax varieties which may be expected due to the differences of these varieties in origin and growth habit, where, these flax cultivars are grown for double purpose crop oil and fibers. Such results are in agreement with those obtained by [29] and [30] they reported that the flax cultivars differed in their productivity.

\subsection{Effect of Humic Acid and Proline on Growth Parameters, Chemical Constituents, Yield and Yield Components of Flax Varieties under Salinity Conditions}

Data presented in Table 4 showed that there were significant differences among all treatments of all studied 
Table 3. Varietal differences among flax varieties in growth, chemical constituents, and yield and yield components under salinity conditions.

\begin{tabular}{|c|c|c|c|c|}
\hline \multirow{2}{*}{ Characters } & \multicolumn{3}{|c|}{ Varieties } & \multirow{2}{*}{$\mathrm{LSD}_{0.05}$} \\
\hline & Opal & Giza-8 & Mayic & \\
\hline Shoot fresh weight (g) & 4.27 & 11.17 & 14.24 & 2.46 \\
\hline Shoot dry weight (g) & 1.02 & 2.93 & 3.78 & 1.07 \\
\hline Chlorophyll a & 12.27 & 12.65 & 10.52 & 0.81 \\
\hline Chlorophyll b & 5.5 & 5.13 & 3.62 & 0.88 \\
\hline Carotenoids & 5.24 & 4.63 & 4.39 & 0.23 \\
\hline Total pigment & 23.01 & 22.4 & 18.53 & 0.79 \\
\hline TSC (mg/100g dry wt.) & 2401 & 1903 & 1581 & 86.15 \\
\hline Free amino acids (mg/100g dry wt.) & 303.05 & 205.20 & 165.72 & 13.06 \\
\hline Proline ( $\mu \mathrm{g} / 100 \mathrm{~g}$ dry wt.) & 55.93 & 43.83 & 39.50 & 2.13 \\
\hline Plant height (cm) & 50.38 & 51.76 & 48.86 & 1.43 \\
\hline Fruiting zone length $(\mathrm{cm})$ & 11.61 & 15.06 & 9.56 & 2.83 \\
\hline Technical length (cm) & 38.77 & 36.71 & 39.31 & 1.11 \\
\hline No. of branches/plant & 4.78 & 7.89 & 5.24 & 0.63 \\
\hline No. of capsules/plant & 8.44 & 14.39 & 6.11 & 2.15 \\
\hline Seed yield/plant (g) & 0.63 & 1.03 & 0.47 & 0.12 \\
\hline Straw yield (ton/ha) & 2.666 & 2.856 & 2.737 & 0.101 \\
\hline Seed yield (ton/ha) & 0.915 & 1.119 & 1.101 & 0.017 \\
\hline Oil (\%) & 30.39 & 33.00 & 33.06 & 2.25 \\
\hline Oil yield (ton/ha) & 0.278 & 0.369 & 0.364 & 0.005 \\
\hline
\end{tabular}

Table 4. Effect of humic acid, proline and their interaction on growth parameters, chemical constituents, yield and yield components under salinity conditions.

\begin{tabular}{|c|c|c|c|c|c|c|c|}
\hline Treatments & Control & HA (50 kg/fed) & P1 (50 mg/L) & P2 (100 mg/L) & $\mathrm{HA}+\mathrm{P} 1$ & $\mathrm{HA}+\mathrm{P} 2$ & $\mathrm{LSD}_{0.05}$ \\
\hline Shoot fresh weight (g) & 6.68 & 9.80 & 7.39 & 8.51 & 10.26 & 16.72 & 2.06 \\
\hline Shoot dry weight (g) & 1.81 & 2.35 & 1.99 & 2.24 & 2.65 & 4.43 & 0.53 \\
\hline Chlorophyll a & 10.74 & 11.93 & 11.11 & 11.66 & 12.22 & 13.21 & 0.85 \\
\hline Chlorophyll b & 3.38 & 5.10 & 4.12 & 4.48 & 5.59 & 5.84 & 0.93 \\
\hline Carotenoids & 4.07 & 4.89 & 4.52 & 4.62 & 5.13 & 5.29 & 0.33 \\
\hline Total pigment & 18.18 & 21.91 & 19.74 & 20.76 & 22.94 & 24.34 & 1.03 \\
\hline TSS (mg/100g dry wt.) & 1441.67 & 1643.33 & 1885.67 & 1934.33 & 2303.67 & 2562.00 & 61.13 \\
\hline Free amino acids (mg/100g dry wt.) & 153.40 & 184.43 & 208.23 & 227.43 & 261.37 & 313.07 & 13.07 \\
\hline Proline ( $\mu g / 100 g$ dry wt.) & 29.47 & 39.07 & 53.90 & 55.63 & 49.57 & 50.90 & 2.35 \\
\hline Plant height (cm) & 42.28 & 49.78 & 48.33 & 48.75 & 53.61 & 59.25 & 1.32 \\
\hline Fruiting zone length $(\mathrm{cm})$ & 7.89 & 11.89 & 11.89 & 11.67 & 13.89 & 15.22 & 0.2 \\
\hline Technical length (cm) & 34.39 & 37.89 & 36.44 & 37.08 & 39.72 & 44.03 & 0.41 \\
\hline No. of branches/plant & 3.55 & 5.78 & 5.34 & 6.11 & 6.81 & 8.22 & 0.32 \\
\hline No. of capsules/plant & 4.55 & 10.11 & 7.89 & 9.11 & 12.00 & 14.22 & 0.63 \\
\hline Seed yield/plant (g) & 0.20 & 0.72 & 0.65 & 0.65 & 0.93 & 1.10 & 0.05 \\
\hline Straw yield (ton/ha) & 1.595 & 3.023 & 2.118 & 2.642 & 3.332 & 3.832 & 0.255 \\
\hline Seed yield (ton/ha) & 0.670 & 1.162 & 0.824 & 0.950 & 1.257 & 1.363 & 0.135 \\
\hline Oil (\%) & 30.39 & 33.00 & 33.06 & 35.64 & 39.09 & 40.86 & 1.25 \\
\hline Oil yield (ton/ha) & 0.204 & 0.383 & 0.273 & 0.339 & 0.492 & 0.557 & 0.052 \\
\hline
\end{tabular}

$\mathrm{HA}$ = humic acid; $\mathrm{P}=$ proline. 
characters under saline conditions. Results indicated that the highest seed yield (1.363 ton/ha), straw yield (3.832 tons/ha) and oil yield ( $0.557 \mathrm{ton} / \mathrm{ha}$ ) were obtained at humic acid (50 kg/fed) with foliar treatment of proline at rate of $(100 \mathrm{mg} / \mathrm{L})$. This may be due to the highest shoot fresh and dry weight per plant, as well as the significant increase in photosynthetic pigment (chlorophyll a, chlorophyll b, carotenoids and total pigments), total soluble sugar and free amino acids content of flax shoots. Also, humic acid and proline increased plant height $(59.25 \mathrm{~cm})$, technical stem length $(44.03 \mathrm{~cm})$, number of fruiting branches/plant (8.22), number of capsules per plant (14.22), seed yield per plant (1.10 g) and oil seed percentage (40.86) compared with the untreated plants. These results are in agreement with those obtained by several investigators [31] and [32]. The superiority of humic acid (50 kg/fed) and foliar treatment of $100 \mathrm{mg} / \mathrm{L}$ proline over the other treatments could be attributed to the stimulatory effects of humic acid on increasing chlorophyll concentration in leaves, it might be also attributed to the low $\mathrm{pH}$ value, as well as increasing the activity of soil micro-organisms to liberate more nutrients from the unavailable reserves. [33] stated that, the increase in berry size because of HA-S application at full bloom is probably ascribed to the uptake of mineral nutrients by the grapevines, but the possible hormone like activity of the HA-S (i.e., auxin-, gibberellin- and cytokinin-like activity) should also be taken into consideration. HA, found to promote soil water holding capacity and reduce watering requirements for plants [34]. Some studies reported that HA could be used as a growth regulator to regulate hormone level, improve plant growth and enhance stress tolerance [35]. HA may stimulate shoot and root growth, and improve resistance to environmental stress in plant, but the physiological mechanism has not been well-established [36].

Moreover, [37] reported that humic substances prevented immobilization of Fe and P and facilitated their translocation from roots to shoots. In addition, [38] suggested that humic substances exert two types of effects in relation to plants, a) indirect effects through acting as suppliers and regulators of plant nutrients similar to synthetic ion exchangers and b) direct effects through uptake of humic substances by plant roots. In this connection, [39] stated that osmotic adjustment within the cytoplasm is maintained by synthesis of compatible solutes, some of which such as proline have deleterious effects on metabolism and growth at high concentrations compared with control treatment.

\subsection{Effect of Interaction between Humic Acid and Proline on Growth Parameters and Chemical Constituents of Three Flax Varieties under Salinity Conditions}

Data in Table 5 indicated that there were significant effects of all interactions between humic acid and proline on growth parameters and chemical constituents of three flax varieties under salinity conditions. Treatment of proline at $(100 \mathrm{mg} / \mathrm{L})$ with humic acid at rate of $(50 \mathrm{~kg} / \mathrm{fed})$ improved plant fresh and dry weight of flax plant in all cultivars of this trail. Fresh weight increased by $66.6 \%, 48.7 \%$ and $65.5 \%$ over controls for Opal, Giza-8 and Mayic varaieties, respectively. [40] have reported that humic substances promoted growth and mineral nutrient uptake of plant due to the better-developed root systems. [41] similarly reported that $1000 \mathrm{~g} \cdot \mathrm{kg}^{-1}$ of HA application positively affected plant growth under saline soil conditions, but higher doses of HA inhibited plant growth. [42] determined that under salt stress, the lowest doses of both soil and foliar application of humic substances increased the nutrient uptake of wheat.

The same table indicate that varieties treated with proline at $(100 \mathrm{mg} / \mathrm{L})$ with humic acid at rate of (50 kg/fed) contained more leaf pigments (chl a, b, carotenoids and total pigments, TSS and free amino acids). It seems that proline employed effectively to increase yield and pigment production. Proline at different concentrations shown to stimulate growth parameters and chemical constituents of flax varieties under salinity conditions [31], cotton [43], and corn [32].

Several investigators reported that proline plays a regulatory role in activity and function of the enzymes catalase, peroxidase and polyphenol oxidase in plant cells and in their participation in development of metabolic responses to environmental factors [44]. The proposed functions of accumulated proline are osmoregulation, maintenance of membrane and protein stability, growth [45] and [46]. It is concluded that exogenous proline with humic acid mitigates the detrimental effects of salt stress to increase the growth parameters and chemical constituents of three flax varieties.

\subsection{Effect of Third Order Interaction (Variety X Humic Acid X Proline) on Growth Parameters, Chemical Constituents, Yield and Yield Components under Salinity Conditions}

The results presented in Table 6 showed that all studied characters significantly affected by the interaction be 
Table 5. Effect of interaction between humic acid, proline and their interaction on growth parameters and chemical constituents of three flax cultivars grown under salinity conditions.

\begin{tabular}{|c|c|c|c|c|c|c|c|c|c|c|}
\hline Varieties & Treatments & $\begin{array}{l}\text { Shoot } \\
\text { Fresh } \\
\text { Weight } \\
\text { (g) }\end{array}$ & $\begin{array}{l}\text { Shoot } \\
\text { Dry } \\
\text { Weight } \\
\text { (g) }\end{array}$ & $\begin{array}{c}\text { Chlorophyll } \\
\text { a }\end{array}$ & $\begin{array}{c}\text { Chlorophyll } \\
\text { b }\end{array}$ & Carotenoids & $\begin{array}{c}\text { Total } \\
\text { Pigment }\end{array}$ & $\begin{array}{c}\text { TSS } \\
\text { (mg/100g } \\
\text { dry wt.) }\end{array}$ & $\begin{array}{c}\text { Free Amino } \\
\text { Acids } \\
\text { (mg/100g } \\
\text { dry wt.) }\end{array}$ & $\begin{array}{c}\text { Proline } \\
\text { ( } \mu \mathrm{g} / 100 \mathrm{~g} \\
\text { dry wt.) }\end{array}$ \\
\hline \multirow{7}{*}{ Opal } & Control & 2.33 & 0.58 & 11.60 & 4.54 & 4.27 & 20.42 & 1720 & 160.3 & 35.7 \\
\hline & HA (50 kg/fed) & 5.43 & 1.10 & 12.23 & 5.35 & 5.52 & 23.10 & 1942 & 218.0 & 51.2 \\
\hline & P1 (50 mg/L) & 2.37 & 0.63 & 11.98 & 5.07 & 5.08 & 22.12 & 2247 & 275.2 & 63.5 \\
\hline & P2 (100 mg/L) & 3.73 & 0.93 & 12.13 & 5.12 & 5.18 & 22.43 & 2301 & 314.5 & 65.4 \\
\hline & $\mathrm{HA}+\mathrm{P} 1$ & 5.43 & 1.41 & 12.83 & 6.42 & 5.61 & 24.86 & 2954 & 385.3 & 58.6 \\
\hline & $\mathrm{HA}+\mathrm{P} 2$ & 6.33 & 1.47 & 12.83 & 6.49 & 5.80 & 25.12 & 3244 & 465.0 & 61.2 \\
\hline & Control & 7.93 & 2.10 & 11.00 & 2.72 & 4.44 & 18.16 & 1342 & 153.4 & 31.2 \\
\hline \multirow{4}{*}{ Giza-8 } & HA (50 kg/fed) & 11.43 & 2.75 & 12.70 & 6.25 & 4.62 & 23.58 & 1530 & 179.2 & 35.7 \\
\hline & P1 (50 mg/L) & 9.13 & 2.57 & 11.32 & 4.23 & 4.45 & 19.99 & 1776 & 188.3 & 51.8 \\
\hline & P2 (100 mg/L) & 10.87 & 2.69 & 12.54 & 4.78 & 4.49 & 21.80 & 1845 & 201.3 & 53.2 \\
\hline & $\mathrm{HA}+\mathrm{P} 1$ & 12.17 & 3.33 & 12.94 & 6.31 & 4.78 & 24.03 & 2236 & 223.0 & 44.3 \\
\hline \multirow{8}{*}{ Mayic } & $\mathrm{HA}+\mathrm{P} 2$ & 15.47 & 4.17 & 15.40 & 6.47 & 4.99 & 26.86 & 2689 & 286.0 & 46.8 \\
\hline & Control & 9.77 & 2.76 & 9.62 & 2.87 & 3.48 & 15.98 & 1263 & 146.5 & 21.5 \\
\hline & HA (50 kg/fed) & 12.53 & 3.20 & 10.85 & 3.70 & 4.52 & 19.06 & 1458 & 156.1 & 30.3 \\
\hline & P1 (50 mg/L) & 10.67 & 2.77 & 10.03 & 3.05 & 4.03 & 17.11 & 1634 & 161.2 & 46.4 \\
\hline & P2 (100 mg/L) & 10.93 & 3.10 & 10.31 & 3.54 & 4.20 & 18.05 & 1657 & 166.5 & 48.3 \\
\hline & $\mathrm{HA}+\mathrm{P} 1$ & 13.17 & 3.21 & 10.89 & 4.04 & 5.01 & 19.94 & 1721 & 175.8 & 45.8 \\
\hline & $\mathrm{HA}+\mathrm{P} 2$ & 28.37 & 7.64 & 11.40 & 4.55 & 5.08 & 21.03 & 1753 & 188.2 & 44.7 \\
\hline & LSD 0.05 & 3.93 & 1.02 & 2.19 & 1.02 & 0.62 & 2.14 & 51.13 & 3.20 & 4.05 \\
\hline
\end{tabular}

$\mathrm{HA}=$ humic acid; $\mathrm{P}=$ proline.

Table 6. Effect of interaction (Varieties X Humic Acid X Proline ) on yield and yield components under salinity conditions.

\begin{tabular}{|c|c|c|c|c|c|c|c|c|c|c|c|}
\hline Varieties & Treatments & $\begin{array}{c}\text { Plant } \\
\text { Height } \\
\text { (cm) }\end{array}$ & $\begin{array}{l}\text { Fruiting } \\
\text { Zone } \\
\text { Length } \\
\text { (cm) }\end{array}$ & $\begin{array}{l}\text { Technical } \\
\text { Length } \\
\text { (cm) }\end{array}$ & $\begin{array}{l}\text { No. of } \\
\text { Branches } \\
\text { /Plant }\end{array}$ & $\begin{array}{l}\text { No. of } \\
\text { Capsules } \\
\text { /Plant }\end{array}$ & $\begin{array}{l}\text { Seed } \\
\text { Yield/ } \\
\text { Plant } \\
\text { (g) }\end{array}$ & $\begin{array}{l}\text { Straw } \\
\text { Yield } \\
\text { (ton/ha) }\end{array}$ & $\begin{array}{l}\text { Seed Yield } \\
\text { (ton/ha) }\end{array}$ & $\begin{array}{l}\text { Oil } \\
(\%)\end{array}$ & $\begin{array}{c}\text { Oil Yield } \\
\text { (ton/ha) }\end{array}$ \\
\hline \multirow{7}{*}{ Opal } & Control & 41.50 & 6.00 & 35.50 & 3.00 & 4.33 & 0.15 & 1.357 & 0.547 & 30.22 & 0.165 \\
\hline & HA (50 kg/fed) & 53.33 & 12.33 & 41.00 & 5.33 & 8.67 & 0.75 & 3.094 & 0.971 & 33.51 & 0.325 \\
\hline & P1 (50 mg/L) & 49.33 & 10.00 & 39.33 & 4.67 & 6.67 & 0.55 & 1.928 & 0.798 & 34.32 & 0.274 \\
\hline & P2 (100 mg/L) & 49.67 & 11.33 & 38.33 & 4.67 & 7.67 & 0.55 & 2.808 & 0.823 & 36.00 & 0.296 \\
\hline & $\mathrm{HA}+\mathrm{P} 1$ & 53.67 & 13.67 & 40.00 & 5.33 & 11.00 & 0.80 & 3.356 & 1.088 & 39.39 & 0.428 \\
\hline & $\mathrm{HA}+\mathrm{P} 2$ & 54.76 & 16.33 & 38.43 & 5.67 & 12.33 & 1.00 & 3.522 & 1.261 & 40.81 & 0.515 \\
\hline & Control & 43.67 & 11.00 & 32.67 & 4.33 & 5.33 & 0.25 & 1.452 & 0.620 & 31.42 & 0.195 \\
\hline \multirow{5}{*}{ Giza-8 } & HA (50 kg/fed) & 53.33 & 13.33 & 40.00 & 6.67 & 15.33 & 1.15 & 3.213 & 1.031 & 35.61 & 0.367 \\
\hline & P1 (50 mg/L) & 48.67 & 17.00 & 31.67 & 6.67 & 11.67 & 0.85 & 2.237 & 0.990 & 36.81 & 0.364 \\
\hline & P2 (100 mg/L) & 49.25 & 14.67 & 34.58 & 8.33 & 13.67 & 1.00 & 2.570 & 1.024 & 39.02 & 0.400 \\
\hline & $\mathrm{HA}+\mathrm{P} 1$ & 53.67 & 17.00 & 36.67 & 9.33 & 18.67 & 1.40 & 3.713 & 1.347 & 42.85 & 0.577 \\
\hline & $\mathrm{HA}+\mathrm{P} 2$ & 62.00 & 17.33 & 44.67 & 12.00 & 21.67 & 1.50 & 3.998 & 1.571 & 44.25 & 0.695 \\
\hline \multirow{6}{*}{ Маyc } & Control & 41.67 & 6.67 & 35.00 & 3.33 & 4.00 & 0.20 & 1.999 & 0.843 & 29.53 & 0.249 \\
\hline & HA (50 kg/fed) & 42.67 & 10.00 & 32.67 & 5.33 & 6.33 & 0.25 & 2.785 & 1.483 & 29.89 & 0.443 \\
\hline & P1 (50 mg/L) & 47.00 & 8.67 & 38.33 & 4.67 & 5.33 & 0.55 & 2.213 & 0.685 & 28.04 & 0.192 \\
\hline & P2 (100 mg/L) & 47.33 & 9.00 & 38.33 & 5.33 & 6.00 & 0.40 & 2.523 & 1.002 & 31.89 & 0.320 \\
\hline & $\mathrm{HA}+\mathrm{P} 1$ & 53.50 & 11.00 & 42.50 & 5.76 & 6.33 & 0.60 & 2.927 & 1.338 & 35.03 & 0.469 \\
\hline & $\mathrm{HA}+\mathrm{P} 2$ & 61.00 & 12.00 & 49.00 & 7.00 & 8.67 & 0.80 & 3.975 & 1.256 & 37.51 & 0.471 \\
\hline & SD 0.05 & 3.12 & 1.16 & 2.12 & 0.31 & 1.30 & 0.11 & 0.210 & 0.042 & 0.57 & 0.021 \\
\hline
\end{tabular}

$\mathrm{HA}=$ humic acid; $\mathrm{P}=$ proline. 
tween humic acid and proline on seed, straw and oil yields of three tested flax varieties. The interaction of proline at $(100 \mathrm{mg} / \mathrm{L})$ with humic acid at rate of $(50 \mathrm{~kg} / \mathrm{fed})$ with Giza-8 variety gave the highest values of seed yield (1.571 ton/ha), straw yield (3.998 ton/ha) and oil yield (0.695 ton/ha). This superiority was due to the obtained highest values of plant height $(62.0 \mathrm{~cm})$, fruiting zone length $(17.33 \mathrm{~cm})$, number of capsules/plant (21.67), number of branches/ plant (12) and seed yield/ plant (1.5 g) and seed oil percentage (44.25) and other chemicals leaf pigments (chl a and b, carotenoids, total pigments, TSS and free amino acids). Proline can also protect cell membranes from salt-induced oxidative stress by enhancing activities of various antioxidants [47]. For example, growth of tobacco suspension cells under salt stress promoted by exogenous application of $10 \mathrm{mM}$ proline, which proposed to be due to proline action as a protectant of enzymes and membranes [17]. In barley embryo cultures under saline conditions, exogenous application of proline resulted in a decrease in $\mathrm{Na}^{+}$and $\mathrm{Cl}^{-}$accumulations and an increase in growth [48]. Such ameliorative effects of proline may be due to plasma membrane stabilization [49].

\section{Conclusion}

This study illustrated that humic acid was able to improve salinity stress tolerance of flax plant. It summarizes the effect of HA and proline on morphology, chemical constituents, yield and yield components of three flax cultivars under salinity conditions. The mechanism that HA can enhance resistance of salinity stress in flax plant may include many possible aspects: HA enhances the absorption of Fe and $\mathrm{P}$ and other nutritional elements, and then improves nutritional status of plant. It activates defense system of plant quickly; they can increase the resistance of plants to environmental stresses by stimulating growth regulators level and involved in protecting the photosynthetic apparatus and consequently increasing the photosynthetic pigments and the photosynthetic machinery and thereby increasing the carbohydrate, nitrogen contents and the growth rate. The most effect treatment observed when cultivating flax plant in the presence of HA with $100 \mathrm{mg} / \mathrm{l}$ proline.

\section{References}

[1] El-Hariri, D.M., Hassanein, M.S. and Ahmed, M.A. (1998) Evaluation of Different Flax Genotypes under Egyptian Conditions. Proceedings Bast Fibrous Plants Today and Tomorrow. N. I. Vavilou Res. INS. Industry (VIR), St. Petersburg.

[2] Darja, K.A. and Trdan, S. (2008) Influence of Row Spacing on the Yield of Two Flax Cultivars (Linum usitatissimum L.). Acta Agriculturae Slovenica, 91, 23-35.

[3] Ghassemi, F., Jakeman, A.J. and Nix, H.A. (1995) Salinization of Land and Water Resources. The University of New South Wales Press, Ltd., Canberra.

[4] Munns, R. (2002) Comparative Physiology of Salt and Water Stress. Plant, Cell \& Environment, 25, 239-250.

[5] Munns, R. and Tester, M. (2008) Mechanisms of Salinity Tolerance. Annual Review of Plant Biology, 59, 651-681.

[6] Souza, R.P., Machado, E.C., Silva, J.A.B., Lagôa, A.M.M.A. and Silveira, J.A.G. (2004) Photosynthetic Gas Exchange, Chlorophyll Fluorescence and Some Associated Metabolic Changes in Cowpea (Vigna unguiculata) during Water Stress and Recovery. Environmental and Experimental Botany, 51, 45-56. http://dx.doi.org/10.1016/S0098-8472(03)00059-5

[7] Senesi, N., Miano, T.M. and Brunetti, G. (1996) Humic-Like Substances in Organic Amendments and Effects on Native Soil Humic Substances. In: Piccolo, A., Ed., Humic Substances in Terrestrial Ecosystems, Elsevier, New York, 531-593. http://dx.doi.org/10.1016/B978-044481516-3/50015-3

[8] Boehme, M., Schevtschenko, J. and Pinker, I. (2005) Iron Supply of Cucumbers in Substrate Culture with Humate. Acta Horticulturae, 41, 329-335.

[9] Yildirim, E. (2007) Foliar and Soil Fertilization of Humic Acid Affect Productivity and Quality of Tomato. Acta Agriculturae Scandinavica Section B-Soil Plant Science, 57, 182-186. http://dx.doi.org/10.1080/09064710600813107

[10] Karakurt, Y., Unlu, H., Unlu, H. and Padem, H. (2009) The Influence of Foliar and Soil Fertilization of Humic Acid on Yield and Quality of Pepper. Acta Agriculturae Scandinavica Section B-Soil Plant Science, 59, 233-237.

[11] Atiyeh, R.M., Edwards, C.A., Metzger, J.D., Lee, S. and Arancon, N.Q. (2002) The Influence of Humic Acids Derived from Earthworm-Processed Organic Wastes on Plant Growth. Bioresource Technology, 84, 7-14. http://dx.doi.org/10.1016/S0960-8524(02)00017-2

[12] Cimrin, K.M. and Yilmaz, I. (2005) Humic Acid Applications to Lettuce Do Not Improve Yield but Do Improve Phosphorus Availability. Acta Agriculturae Scandinavica, Section B-Soil \& Plant Science, 55, 58-63. 
[13] Matysik, J., Alai, Bhalu, B. and Mohanty, P. (2002) Molecular Mechanisms of Quenching of Reactive Oxygen Species by Proline under Stress in Plants. Current Science, 82, 525-532.

[14] Khedr, A.H.A., Abbas, M.A., Wahid, A.A.A., Quick, W.P. and Abogadallah, G.M. (2003) Proline Induces the Expression of Salt-Stress Responsive Proteins and May Improve the Adaptation of Pancratium maritimum L. to Salt-Stress. Journal of Experimental Botany, 54, 2553-2562. http://dx.doi.org/10.1093/jxb/erg277

[15] Ashraf, M., Athar, H.R., Harris, P.J.C. and Kwon, T.R. (2008) Some Prospective Strategies for Improving Crop Salt Tolerance. Advances in Agronomy, 97, 45-110. http://dx.doi.org/10.1016/S0065-2113(07)00002-8

[16] Heuer, B. (2003) Influence of Exogenous Application of Proline and Glycinebetaine on Growth of Salt-Stressed Tomato Plants. Plant Science, 165, 693-699. http://dx.doi.org/10.1016/S0168-9452(03)00222-X

[17] Okuma, E., Soeda, K., Tada, M. and Murata, Y. (2000) Exogenous Proline Mitigates the Inhibition of Growth of Nicotiana tabacum Cultured Cells under Saline Conditions. Soil Science and Plant Nutrition, 46, 257-263. http://dx.doi.org/10.1080/00380768.2000.10408781

[18] Okuma, E., Murakami, Y., Shimoishi, Y., Tada, M. and Murata, Y. (2004) Effects of Exogenous Application of Proline and Betaine on the Growth of Tobacco Cultured Cells under Saline Conditions. Soil Science and Plant Nutrition, 50, 1301-1305. http://dx.doi.org/10.1080/00380768.2004.10408608

[19] Ben Ahmed, C., Ben Rouina, B., Sensoy, S., Boukhriss, M. and Ben Abdullah, F. (2010) Exogenous Proline Effects on Photosynthetic Performance and Antioxidant Defense System of Young Olive Tree. Journal of Agricultural and Food Chemistry, 58, 4216-4222. http://dx.doi.org/10.1021/jf9041479

[20] Chapman, H.D. and Pratt, P.F. (1978) Methods of Analysis for Soils, Plant and Water. University of California Division of Agriculture Science, California.

[21] Lichtenthaler, H.K. and Buschmann, C. (2001) Chlorophylls and Carotenoids: Measurement and Characterization by UV-VIS Spectroscopy. In: Wrolstad, R.E., Acree, T.E., An, H., Decker, E.A., Penner, M.H., Reid, D.S., Schwartz, S.J., Shoemaker, C.F. and Sporns, P., Eds., Current Protocols in Food Analytical Chemistry (CPFA), John Wiley and Sons, New York, F4.3.1-F4.3.8.

[22] Prud'homme, M.P., Gonzalez, B., Billard, J. and Boucaud, J. (1992) Carbohydrate Content, Fructan and Sucrose Enzyme Activities in Roots, Stubble and Leaves of Rye Grass (Lolium perenne L.) as Affected by Sources/Sink Modification after Cutting. Journal of Plant Physiology, 140, 282-291. http://dx.doi.org/10.1016/S0176-1617(11)81080-1

[23] Yemm, E.W. and Willis, A.J. (1954) The Respiration of Barley Plants. IX. The Metabolism of Roots during Assimilation of Nitrogen. New Phytologist, 55, 229-234. http://dx.doi.org/10.1111/j.1469-8137.1956.tb05283.x

[24] Bates, L.S., Waldan, R.P. and Teare, I.D. (1973) Rapid Determination of Free Proline under Water Stress Studies. Plant and Soil, 39, 205-207. http://dx.doi.org/10.1007/BF00018060

[25] Vartainan, N., Hervochon, P., Marcotte, L. and Larher, F. (1992) Proline Accumulation during Drought Rhizogenesis in Brassica napus var. Oleifera. Journal of Plant Physiology, 140, 623-628. http://dx.doi.org/10.1016/S0176-1617(11)80799-6

[26] Yemm, E.W., Cocking, E.C. and Ricketts, R.E. (1955) The Determination of Amino Acids with Ninhydrin. Analyst, 80, 209-214. http://dx.doi.org/10.1039/an9558000209

[27] Kates, M. and Eberhardt, F.M. (1957) Isolation and Fractionation of Leaf Phosphatides. Canadian Journal of Botany, 35, 895-905. http://dx.doi.org/10.1139/b57-074

[28] Snedecor, G.W. and Cochran, W.G. (1980) Statistical Methods. 7th Edition, The Iowa State University Press, Ames.

[29] El-Hariri, D.M, Hassanein, M.S. and El-Sweify, A.H. (2004) Evaluation of Same Flax Varieties, Straw Yield, Yield Components and Technological Characters. Agricultural Research, 75, 697-715.

[30] Bakry, A.B., Sadak, M.Sh., Moamen, H.T. and Abd El Lateef, E.M. (2013) Influence of Humic Acid and Organic Fertilizer on Growth, Chemical Constituents, Yield and Quality of Two Flax Seed Cultivars Grown under Newly Reclaimed Sandy Soils. International Journal of Academic Research, 5, 125-134. http://dx.doi.org/10.7813/2075-4124.2013/5-5/A.17

[31] Darwish, S.M. and Reda, F. (1975) Effect of Lysine and Proline on Alkaloidal Content of Nicotiana rustica L. in Relation to Growth and Flowering. Proceedings of 14th Conference of Pharmaceutical Science, Cairo.

[32] Hamed, A.A. and Al-Wakeel, S.A. (1994) Physiological Response of Zea mays Exposed to Salinity and to Exogenous Proline. Egyptian Journal of Botany, 34, 93-105.

[33] Ferrara, G. and Brunetti, G. (2010) Effects of the Times of Application of a Soil Humic Acid on Berry Quality of Table Grape (Vitis vinifera L.) cv Italia. Spanish Journal of Agricultural Research, 8, 817-822. http://dx.doi.org/10.5424/1283

[34] Hynes, R.J. and Naidu, R. (1998) Influence of Lime, Fertilizer and Manure Application on Soil Organic Matter Content and Soil Physical Conditions: A Review. Nutrient Cycling in Agroecosystems, 51, 123-137. 
[35] Piccolo, A., Nardi, S. and Concheri, G. (1992) Structural Characteristics of Humic Substance as Related to Nitrate Uptake and Growth Regulation in Plant Systems. Soil Biology and Biochemistry, 24, 373-380. http://dx.doi.org/10.1016/0038-0717(92)90197-6

[36] Delfine, S., Tognetti, R., Desiderio, E. and Alvino, A. (2005) Effect of Foliar Application of N and Humic Acids on Growth and Yield of Durum Wheat. Agronomy for Sustainable Development, 25, 183-191. http://dx.doi.org/10.1051/agro:2005017

[37] Dekock, P.C. (1955) Influence of Humic Acids in Plant Growth. Science, 121, 573-474.

[38] Schnitzer, M. and Khan, S.U. (1972) Humic Substances in the Environment. Marcel Dekker, Inc., New York.

[39] Mazhar, A.M., Shedeed, S.I., Abdel-Aziz, N.G. and Mahgoub, M.H. (2012) Growth, Flowering and Chemical Constituents of Chrysanthemum indicum L. Plant in Response to Different Levels of Humic Acid and Salinity. Journal of Applied Sciences Research, 8, 3697-3706.

[40] David, P.P., Nelson, P.V. and Sanders, D.C. (1994) A Humic Acid Improves Growth of Tomato Seedling in Solution Culture. Journal of Plant Nutrition, 17, 173-184. http://dx.doi.org/10.1080/01904169409364717

[41] Türkmen, O., Dursun, A., Turan, M. and Erdinc, C. (2004) Calcium and Humic Acid Affect Seed Germination, Growth and Nutrient Content of Tomato (Lycopersicon esculentum L.) Seedlings under Saline Soil Conditions. Acta Agriculturae Scandinavica, Section B-Soil \& Plant Science, 54, 168-174.

[42] Asik, B.B., Turan, M.A., Celik, H. and Katkat, A.V. (2009) Effects of Humic Substances on Plant Growth and Mineral Nutrients Uptake of Wheat (Triticum durum cv. Salihli) under Conditions of Salinity. Asian Journal of Crop Science, 1, 87-95. http://dx.doi.org/10.3923/ajcs.2009.87.95

[43] Heikal, M.M.D. and Shaddad, M.A. (1982) Alleviation of Osmotic Stress on Seed Germination and Seedling Growth of Cotton, Pea and Wheat by Proline. Phyton, 22, 275-287.

[44] Ozturk, L. and Demir, Y. (2002) In Vivo and in Vitro Protective Role of Proline. Plant Growth Regulation, 38, $259-264$. http://dx.doi.org/10.1023/A:1021579713832

[45] Hare, P.D., Cress, W.A. and van Staden, J. (2003) A Regulatory Role for Proline Metabolism in Stimulating Arabidopsis thaliana Seed Germination. Plant Growth Regulation, 39, 41-50. http://dx.doi.org/10.1023/A:1021835902351

[46] Wahba, H.E., Motawe, H.M., Ibrahim, A.Y. and Mohamed, A.H. (2007) The Influence of Amino Acids on Productivity of Urtica Pilulifera Plant. 3rd International Conference of Pharmaceutical and Drug Industries Division, National Research Council, Cairo.

[47] Yan, H., Gang, L.Z., Zhao, C.Y. and Guo, W.Y. (2000) Effects of Exogenous Proline on the Physiology of Soyabean Plantlets Regenerated from Embryos in Vitro and on the Ultrastructure of Their Mitochondria under NaCl Stress. Soybean Science, 19, 314-319.

[48] Lone, M.I., Kueh, J.S.H., Wyn Jones, R.G. and Bright, S.W.J. (1987) Influence of Proline and Glycinebetaine on Salt Tolerance of Cultured Barley Embryos. Journal of Experimental Botany, 38, 479-490. http://dx.doi.org/10.1093/jxb/38.3.479

[49] Mansour, M.M.F. (1998) Protection of Plasma Membrane of Onion Epidermal Cells by Glycinebetaine and Proline against $\mathrm{NaCl}$ Stress. Plant Physiology and Biochemistry, 36, 767-772. http://dx.doi.org/10.1016/S0981-9428(98)80028-4 
Scientific Research Publishing (SCIRP) is one of the largest Open Access journal publishers. It is currently publishing more than 200 open access, online, peer-reviewed journals covering a wide range of academic disciplines. SCIRP serves the worldwide academic communities and contributes to the progress and application of science with its publication.

Other selected journals from SCIRP are listed as below. Submit your manuscript to us via either submit@scirp.org or Online Submission Portal.
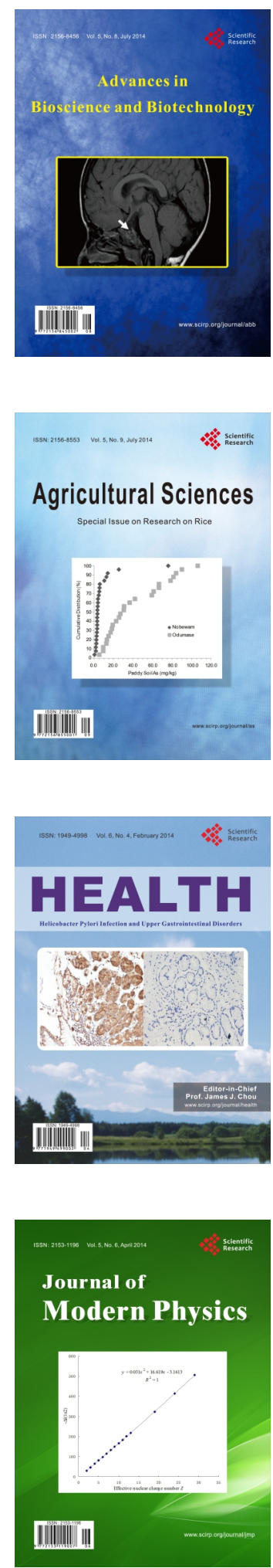
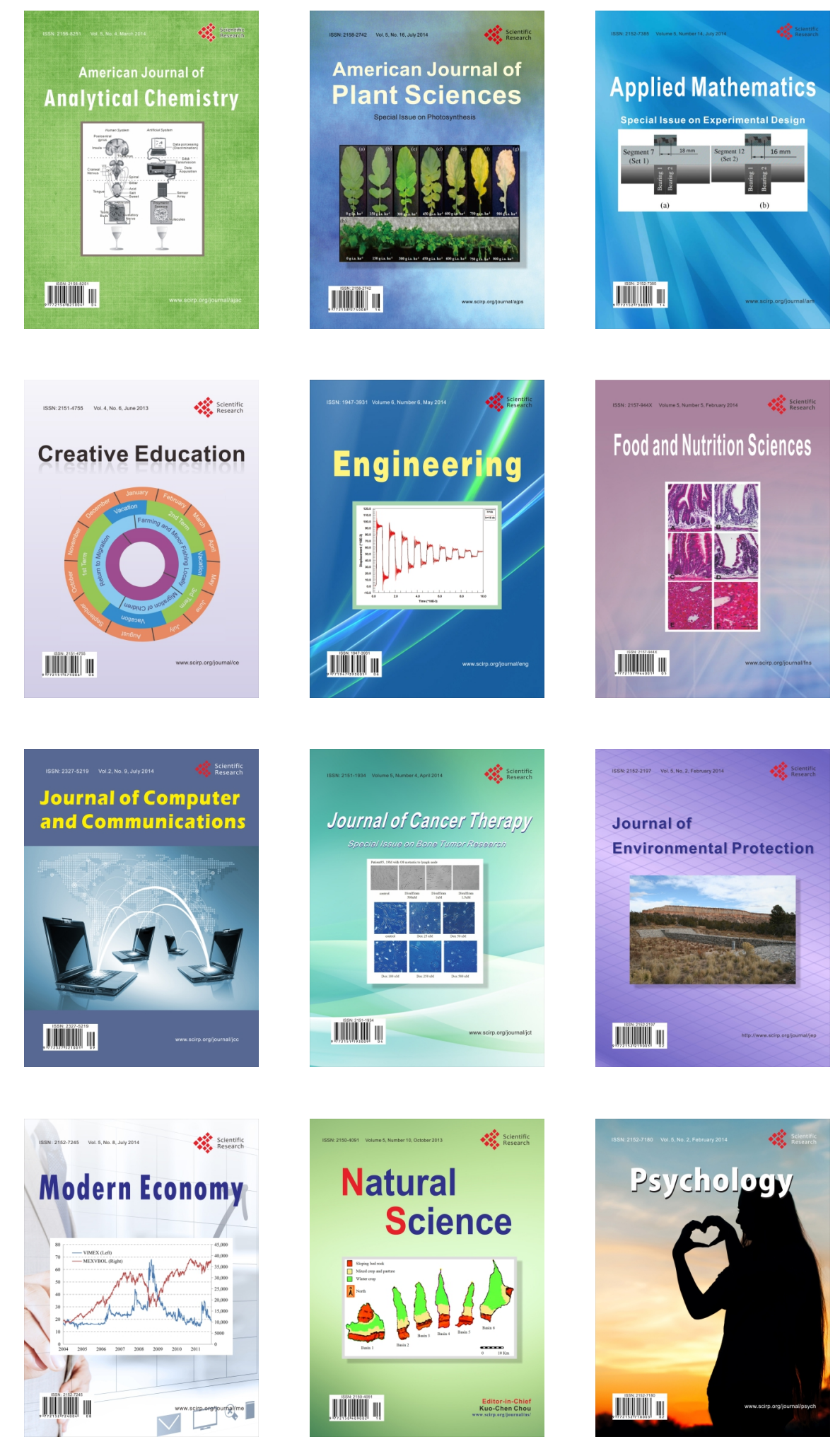